\title{
Body posture and pulmonary function in mouth and nose breathing children: cross-sectional study
}

\author{
Postura corporal e função pulmonar em crianças \\ respiradoras orais e nasais: estudo transversal
}

Jovana de Moura Milanesi, Fernanda Pasinato, Luana Cristina Berwig, Ana Maria Toniolo da Silva,
Eliane Castilhos Rodrigues Corrêa*

Universidade Federal de Santa Maria (UFSM), Santa Maria, RS, Brazil

\begin{abstract}
Introduction: Mouth breathing can lead to changes in body posture and pulmonary function. However, the consequences are still inconclusive and a number of studies are controversial. Objective: Evaluate and correlate spirometric parameters and postural measures in mouth breathing children, and compare them to nose breathers. Methods: two groups of 6 to 12 year-old children were evaluated: mouth breathers $(M B, n=55)$ and nose breathers $(\mathrm{NB}, \mathrm{n}=45)$. Spirometry and body posture analysis using photogrammetry (SAPo $0.68 \AA$ v) were carried out. The following spirometric measures were evaluated: peak expiratory flow (PEF), forced expiratory volume in 1 second (FEV1), forced vital capacity (FVC), FEV1/FVC ratio (\%) and forced expiratory flow between 25\% and 75\% of FVC (FEF 25-75\%). Biophotogrammetric measures analyzed were: horizontal alignment of acromions (HAA) and anterior superior iliac spine (HAASIS), Charpy angle, horizontal alignment of the head (HAH), cervical lordosis (CL), thoracic kyphosis (TK), lumbar lordosis (LL), cervical distance (CD) and lumbar distance (LD). Results: There were no intergroup differences in spirometric and postural variables. Positive and moderate correlations were found between CL and CD measures with PEF, FEV1, FVC and FEF 2575\%, while weak correlations were observed between lumbar lordosis and PEF, FEV1 and FVC. Conclusion: The breathing mode had no influence on postural and respiratory measures. However, greater forward head posture, with smaller cervical lordosis, was related to higher lung volumes and flows in both groups.
\end{abstract}

Keywords: Mouth Breathing. Spirometry. Posture.

\footnotetext{
* JMM: PhD, email: jovanamil@yahoo.com.br FP: PhD, email: fepas.fisio@yahoo.com.br LCB: Doctoral student, email: luanaberwig@gmail.com AMTS: PhD, email: amariatoniolo@gmail.com ECRC: PhD, email: eliftrs@yahoo.com.br
} 


\section{Resumo}

Introdução: A respiração oral pode levar a alterações na postura corporal e na função pulmonar. Entretanto, tais implicações ainda são inconclusivas e alguns estudos são controversos. Objetivo: avaliar e correlacionar parâmetros espirométricos e medidas posturais em crianças respiradoras orais, comparando-as com respiradores nasais. Métodos: foram avaliadas crianças de 6 a 12 anos que compuseram os grupos: respiradores orais $(R O, n=55)$ e nasais ( $R N, n=45)$. Foram realizadas espirometria e análise da postura corporal, por meio de biofotogrametria (SAPo v 0.68®). As medidas de espirometria utilizadas foram: pico de fluxo expiratório (PFE), volume expiratório forçado no primeiro segundo (VEF1), capacidade vital forçada (CVF), relação VEF1/CVF (\%) e fluxo expiratório forçado entre 25\% e 75\% da CVF (FEF25-75\%). As medidas biofotogramétricas analisadas foram: alinhamento horizontal dos acrômios (AHA) e das espinhas ilíacas ântero-superiores (AHEIAS), ângulo de Charpy, alinhamento horizontal da cabeça (AHC), lordose cervical (LC), cifose torácica (CT), lordose lombar (LL), distância cervical (DC) e distância lombar (DL). Resultados: Não houve diferença entre os grupos nas variáveis espirométricas e posturais. Foram encontradas correlações positivas e moderadas entre as medidas posturais LC e DC e as medidas de PFE, VEF1, CVF e FEF25-75\%. Ainda, correlações fracas entre DL e PFE, VEF1 e CVF foram encontradas. Conclusão: Na amostra estudada, o modo respiratório não gerou influência nas medidas posturais e respiratórias. Porém, a maior projeção anterior da cabeça com menor lordose cervical se relacionou com maiores volumes e fluxos pulmonares, em ambos os grupos.

Palavras-chave: Respiração Bucal. Espirometria. Postura.

\section{Introduction}

Mouth breathing in childhood, commonly associated with pulmonary and postural changes, may be obstructive or functional in origin $(1,2,3,4)$. Obstructive origins are more common and have multiple causes, such as nasal mucosal congestion secondary to allergic rhinitis, anatomical deformities of nasal cavities, nasal turbinate hypertrophy, adenoid hypertrophy and palatine tonsil hypertrophy $(5,6,7)$.

Despite the pulmonary compromise attributed to mouth breathing, there are few studies investigating the relationship between spirometric parameters and breathing mode. Silveira et al. (3) assessed pulmonary function parameters using spirometry in mouth breathing children, obtaining statistically lower forced expiratory volume in one second (FEV1), forced vital capacity (FCV), and FEV1/FCV ratio (\%) values. Milanesi et al. (1) used a portable flow meter to measure peak expiratory flow in adults with a history of mouth breathing in childhood, finding no differences compared to adults with no breathing complaints. In this respect, results seem to be scarce and inconclusive.

Postural changes are common in school age children, a period in which transitory postural patterns are necessary to adapt to new body proportions $(8,9)$. However, it is believed that to facilitate the entry of air via the oropharynx, mouth breathers develop forward head posture $(2,10)$. Thus, muscular imbalance occurs, including not only the neck muscles, but also the scapular waist, rib cage, abdominal and pelvic muscles, which are distributed in a functionally interdependent network. Thus, it is assumed that postural changes may be associated with mouth breathing, as a compensatory mechanism to improve respiratory function in children.

Biophotogrammetry, a reliable postural assessment method in both adults and children, may help in the detection and intervention in disorders of the developing musculoskeletal system $(8,11)$. With respect to head posture, biophotogrammetric measures may be useful in identifying postural changes, such as forward head posture. Weber et al. (12) found significant correlations between biophotogrammetric measures of craniocervical posture and corresponding cephalometric measures. However, there are few biophotogrammetric measures with reference values in the literature.

Given that studies on the association between spirometric parameters and body posture in mouth and nose breathing children are still scarce and inconclusive, there is a need for further clarification on the subject. Thus, the aim of the present study was to assess and correlate spirometric parameters and postural measures with respect to the spine (cervical, 
thoracic and lumbar), shoulders and pelvis in mouth breathers aged between 6 and 12 years, and compare them to nose breathers.

\section{Methods}

This cross-sectional study was approved by the Research Ethics Committee of the Federal University of Santa Maria (UFSM) under protocol number 08105512.0.0000.5346. After all the subjects and their parents or legal guardians were informed of the procedures, ensuring their confidentiality and physical and mental integrity, the latter gave their informed consent in accordance with resolution 466/12 of the National Health Council (CNS).

\section{Sample}

The children that took part in this study were enrolled in public schools in Santa Maria, Rio Grande do Sul (RS) state, characterizing a convenience sample. The study was conducted (sample selection and data collection) in December 2013 and April 2015. The following inclusion criteria were adopted: age between 6 and 12 years, mixed and/or permanent dentition, agreement to participate in the research in the form of a consent form signed by the parents or legal guardians.

Exclusion criteria were: clear signs of neurological compromise and/or craniofacial malformations, bout of allergic rhinitis in the previous 30 days, use of oral or topical antihistamines or corticotherapy in the previous 30 days, undergoing orthodontic, speech therapy and/or physiotherapy treatment and prior history of surgery or facial trauma.

After assessment, the children were divided into mouth and nose breathing groups. Three aspects were considered in mouth breathing diagnosis: parent-reported history of mouth breathing in the last 6 months, assessment of breathing mode by a speech therapist and an ENT (ear, nose and throat) doctor. Speech therapy assessment considered the following for breathing mode diagnosis: lack of lip sealing at assessment and positive breathing tests based on the MBGR protocol of orofacial myofunctional evaluation (13). In addition to observing the open mouth during evaluation, the ENT examination considered the presence of obstructive and/or functional factors, determined by visual inspection and nasal endoscopy.

\section{Procedures}

\section{Spirometry}

A spirometric examination was conducted by an independent blind evaluator, in line with the Guidelines for Pulmonary Function Tests (14), using a portable spirometer (One FlowClement Clarke, United Kingdom). The children's weight (Digital Techline Scale, Brazil) and height were measured.

The FVC maneuver was used to determine the following spirometric parameters: peak expiratory flow (PEF), forced expiratory volume in one second (VEF1), forced vital capacity (FVC), FEV1/ FVC ratio (\%) and forced expiratory flow between $25 \%$ and $75 \%$ of FEF (FEF25-75\%). Valid results met the criteria of acceptability and reproducibility, where two technically suitable maneuvers that did not differ by more than $10 \%$ were selected, the higher of which was accepted. Spirometries were interpreted and respiratory disorders quantified according to the Guidelines for the Pulmonary Function Test (14).

\section{Postural examination}

Body posture was assessed based on a photographic record with biophotogrammetric analysis using the $S A P$ o v $0.68^{\circledR}$ program. Photographs were taken with subjects in the upright position from anterior and right lateral views. The children wore swimsuits, were barefoot and their hair was tied when necessary (for better visualization). Markers were placed on anatomical points on the children's bodies using previously prepared white Styrofoam balls with double-sided tape. Photographs were taken against a black background, using an adjustable tripod (Vanguard ${ }^{\circledR}$ - VT 131) and digital camera (Sony ${ }^{\circledR}$ Cybershot 7.2 megapixels). The tripod was positioned at least 3 meters from the subject at approximately half the child's height. Photographs were taken and analyzed by an evaluator with more than five years' experience, blind to the breathing mode of the subjects.

The posture measures analyzed are shown in Figure 1. All the measures are expressed in angles, except cervical and lumbar distances, which are expressed in centimeters. 


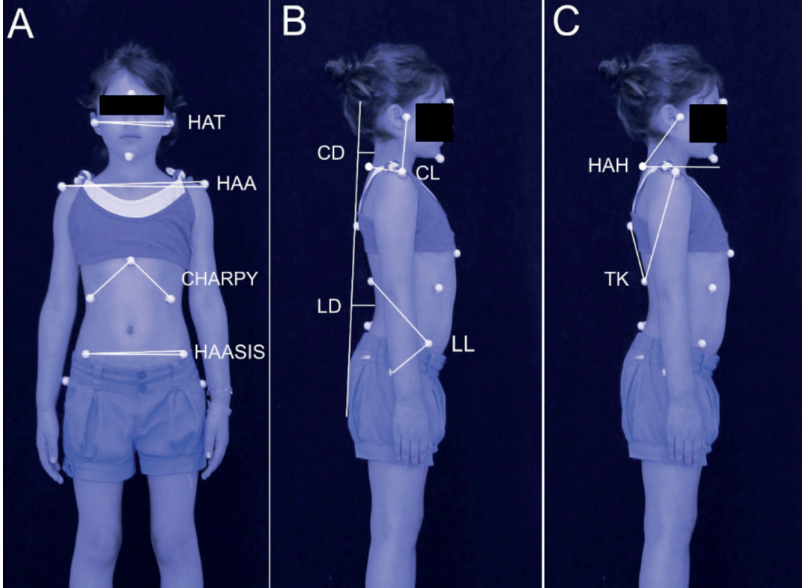

Figure 1 - Biophotogrammetric postural measures. A) HAT: horizontal alignment of the tragus of the ears; HAA: horizontal alignment of acromions; HAASIS: horizontal alignment of the anterior superior iliac spine; B) CD: cervical distance; LD: lumbar distance; CL: cervical lordosis; LL: lumbar lordosis; C) HAH: horizontal alignment of the head; TK: thoracic kyphosis.

Higher HAT angles reflect greater head tilt. Higher HAA and HAASIS angles signify greater shoulder asymmetry and pelvis misalignment, respectively. The greater the Charpy angle (15), the more horizontal the ribs. In the side view, HAH (16) demonstrates the greatest forward head posture and lowest angles. Higher CL angles indicate more head posture, less cervical lordosis and high TK and LL values, as well as greater thoracic and lumbar lordosis (4). The increase in $\operatorname{CD}(12,17,18)$ can be interpreted as greater forward head posture and high $\operatorname{LD}(17,18)$ as greater lumbar lordosis.

\section{Data analysis}

Sample calculation for studies comparing two groups and studies that correlate quantitative variables was performed using the GPower 3.0.10 program. An effect size of 0.8 and power of 0.95 was considered for intergroup comparison and effect size of 0.5 and power of 0.95 for correlation between variables, both with an alpha of $5 \%$. The minimum number was determined to be 84 individuals.

STATISTICA 9.0 (Statistica for Windows - release 9.0 Stat Soft) and SPSS (Statistical Package for the Social Sciences) were used for inferential analyses. The Lilliefors test was used to check data normality. Since the variables were nonparametric, the groups were compared using the Mann-Whitney U test. Correlations were calculated by Spearman's Correlation Coefficient. The correlation was considered strong for $\mathrm{r}$ values $\geq$ 0.7 ; moderate for $0.3<r<0.7$ and weak for $0<r<0.3$ (19). The significance level for all the tests was set at an alpha of $5 \%$.

\section{Results}

Figure 2 shows the flowchart of the sample selection process. A total of 55 children, with mean ages of 8.65 years ( \pm 1.67 years), 31 boys and 24 girls, were classified as mouth breathers (MB). The nose breathing (NB) group was composed of 45 children with mean ages of 8.33 years ( \pm 1.56 years), 19 boys and 26 girls. All the children exhibited normal respiratory function as measured by the spirometric examination.

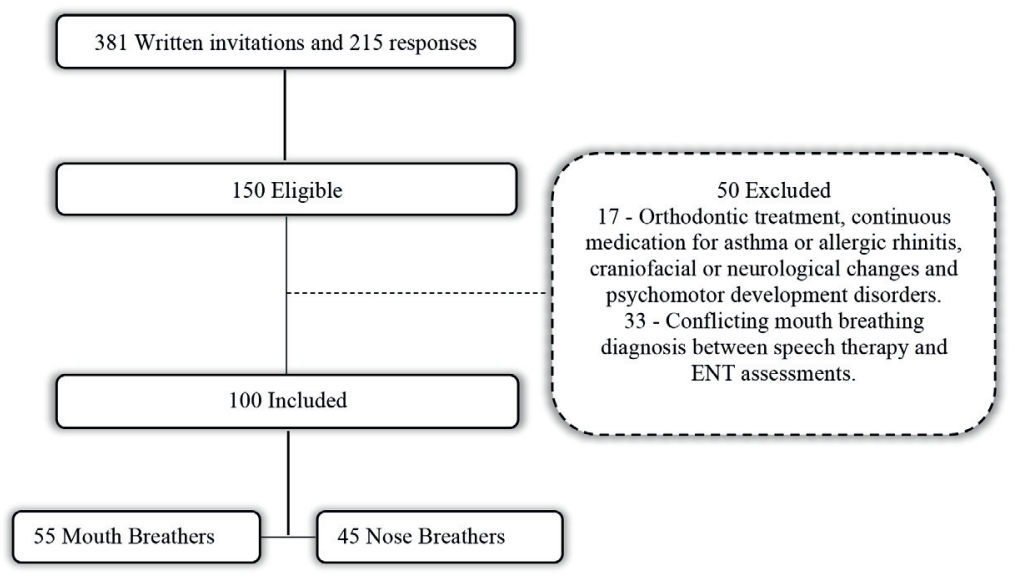

Figure 2 - Sample selection flowchart. 
Tables 1 and 2 show data for the spirometric and postural variables of the two groups. Both spirometric and postural variables exhibited similar intergroup behavior, with no statistically significant difference.

Table 1 - Spirometric variables in the MB and NB groups

\begin{tabular}{|c|c|c|c|}
\hline \multirow{2}{*}{$\begin{array}{l}\text { Spirometric } \\
\text { variables }\end{array}$} & $M B(n=55)$ & NB $(n=45)$ & \multirow[b]{2}{*}{$p$} \\
\hline & $\begin{array}{l}\text { Median } \\
\left(\mathbf{I} \mathbf{R}_{25-75 \%}\right) \\
\end{array}$ & $\begin{array}{c}\text { Median } \\
\left(\mathbf{I R}_{25-75 \%}\right)\end{array}$ & \\
\hline PEF (I/min) & $245(210-275)$ & $240(210-280)$ & 0.760 \\
\hline FEV1 (I) & $1.85(1.55-2.25)$ & $1.80(1.50-2.15)$ & 0.953 \\
\hline FCV (I) & $2.10(1.65-2.35)$ & $1.95(1.70-2.45)$ & 0.763 \\
\hline FEV1/FVC (\%) & $100(94-100)$ & $100(95-100)$ & 0.814 \\
\hline FEF25-75\% (I) & $2.65(2.25-3.10)$ & $2.75(2.40-3.15)$ & 0.600 \\
\hline
\end{tabular}

Note: Mann-Whitney Test. MB: mouth breather; NB: nose breather; IR25-75\%: Interquartile range 25-75\%; PEF: peak expiratory flow; $\mathrm{V}$ min: liters per minute; FEV1: forced expiratory flow in one second; I: liters; FVC: forced vital capacity; FEV1/FVC: ratio between forced expiratory volume in one second and forced vital capacity; \%: percentage; $\mathrm{FEF}_{25-75 \%}$ : forced expiratory flow between 25 and $75 \%$ of FVC.

Table 2 - Postural variables in MB and NB groups

\begin{tabular}{|c|c|c|c|}
\hline \multirow{2}{*}{$\begin{array}{l}\text { Postural } \\
\text { variables }\end{array}$} & $M B(n=55)$ & NB $(n=45)$ & \multirow[b]{2}{*}{$p$} \\
\hline & $\begin{array}{l}\text { Median } \\
\left(\mathbf{I R}_{25-75 \%}\right)\end{array}$ & $\begin{array}{c}\text { Median } \\
\left(\mathbf{I} \mathbf{R}_{25-75 \%}\right)\end{array}$ & \\
\hline HAT $\left(^{\circ}\right)$ & $2.4(1.1-4.2)$ & $2.0(0.7-2.8)$ & 0.244 \\
\hline HAA $\left(^{\circ}\right)$ & $1.5(0.6-2.6)$ & $1.5(0.7-2.3)$ & 0.731 \\
\hline HAASIS $\left({ }^{\circ}\right)$ & $1.5(0.5-2.4)$ & $1.1(0.5-2.1)$ & 0.324 \\
\hline Charpy $\left({ }^{\circ}\right)$ & $\begin{array}{c}102.7 \\
(96.2-109.8)\end{array}$ & $\begin{array}{c}101.3 \\
(98.2-107.4)\end{array}$ & 0.989 \\
\hline HAH $\left(^{\circ}\right)$ & $46.4(41.0$ - 49.9) & $45.0(42.0$ - 49.6) & 0.758 \\
\hline $\begin{array}{l}\text { Cervical } \\
\text { Lordosis }\left({ }^{\circ}\right)\end{array}$ & $61.5(52.8-68.7)$ & $62.2(54.6-70.8)$ & 0.410 \\
\hline $\begin{array}{l}\text { Thoracic } \\
\text { Kyphosis }\left({ }^{\circ}\right)\end{array}$ & $30.0(26.3-34.3)$ & $30.8(27.1$ - 32.3) & 0.410 \\
\hline $\begin{array}{l}\text { Lumbar } \\
\text { Lordosis }\left({ }^{\circ}\right)\end{array}$ & 85.9 (81.7 - 89.8) & 85.0 (77.2 - 90.9) & 0.373 \\
\hline $\begin{array}{c}\text { Cervical } \\
\text { Distance (cm) }\end{array}$ & $6.0(5.0-7.3)$ & $6.2(5.0-7.1)$ & 0.956 \\
\hline $\begin{array}{c}\text { Lumbar } \\
\text { Distance (cm) }\end{array}$ & $5.2(3.9-6.2)$ & $5.1(4.5-5.9)$ & 0.721 \\
\hline
\end{tabular}

Note: Mann-Whitney U test. MB: mouth breather; NB: nose breather; $\mathbb{R}_{25-75} \%$ : Interquartile range $25-75 \%$; HAT: horizontal alignment of the tragus of the ears; HAA: horizontal alignment of the acromions; HAASIS: horizontal alignment of the anterior superior iliac spine; HAH: horizontal alignment of the head; $\mathrm{cm}$ : centimeters.
Since the two groups exhibited similar behavior in both spirometric and postural variables, the sample was combined $(\mathrm{n}=100)$ for correlation analysis. The correlation coefficients between spirometric variables and cervical, thoracic and lumbar postural measures are show in Table 3.

Table 3 - Correlation coefficients $(r)$ between spirometric and postural variables

\begin{tabular}{cccccc}
\hline Variables & $\begin{array}{c}\text { PEF } \\
(\mathbf{n}=100)\end{array}$ & $\begin{array}{c}\text { FEV1 } \\
(\mathbf{n}=100)\end{array}$ & $\begin{array}{c}\text { FVC } \\
(\mathbf{n}=100)\end{array}$ & $\begin{array}{c}\text { FEV1/FVC } \\
(\mathbf{n}=100)\end{array}$ & $\begin{array}{c}\text { FEF25- } \\
\mathbf{7 5} \% \\
(\mathbf{n}=100)\end{array}$ \\
\hline HAT & $-0.288^{* *}$ & -0.176 & -0.176 & 0.057 & $-0.225^{*}$ \\
HAA & -0.089 & -0.035 & -0.022 & 0.111 & -0.043 \\
HAASIS & 0.038 & -0.045 & -0.025 & $-0.219^{*}$ & -0.110 \\
Charpy & 0.003 & 0.057 & 0.063 & 0.024 & 0.130 \\
HAH & 0.055 & 0.008 & -0.012 & -0.031 & 0.083 \\
$\begin{array}{c}\text { Cervical } \\
\text { Lordosis }\end{array}$ & $0.354^{* *}$ & $0.363^{* *}$ & $0.349^{* *}$ & -0.109 & $0.383^{* *}$ \\
$\begin{array}{c}\text { Thoracic } \\
\text { Kyphosis }\end{array}$ & -0.098 & -0.143 & -0.167 & 0.073 & -0.047 \\
$\begin{array}{c}\text { Lumbar } \\
\text { Lordosis }\end{array}$ & 0.017 & -0.029 & 0.073 & -0.093 & -0.121 \\
$\begin{array}{c}\text { Cervical } \\
\text { Distance }\end{array}$ & $0.487^{* *}$ & $0.559^{* *}$ & $0.519^{* *}$ & -0.092 & $0.511^{* *}$ \\
$\begin{array}{c}\text { Lumbar } \\
\text { Distance }\end{array}$ & $0.230^{*}$ & $0.233^{* *}$ & $0.246^{*}$ & $-0.228^{*}$ & $0.474^{* *}$ \\
\hline
\end{tabular}

Note: Spearman's correlation test; ${ }^{*} p<0.05 ;{ }^{* *} p<0.001$. PEF: peak expiratory flow; FEV: forced expiratory flow in one second; FVC: forced vital capacity; FEV1/FVC: ratio between forced expiratory volume in one second and forced vital capacity; \%: percentage; FEF2575\%: forced expiratory flow between 25 and $75 \%$ of FVC; HAT: horizontal alignment of the tragus of the ears; HAA: horizontal alignment of the acromions; HAASIS: horizontal alignment of the anterior superior iliac spine; HAH: horizontal alignment of the head; $\mathrm{cm}$ : centimeters.

HAT showed a weak significant negative correlation with PEF and FEF25-75\%. The HAASIS angle exhibited a weak significant negative correlation with FEV1/FVC $\%$. Moderate significant positive correlations were observed between cervical measures (cervical distance and cervical lordosis) and all respiratory parameters assessed except FEV1/FVC\%. Lumbar distance was weak and positively related to PEF, FEV1 and FVC and moderately to FEF25-75\%. The correlation between lumbar distance and FEV1/FVC\% was negative and weak. 


\section{Discussion}

The children assessed in this study exhibited similar postural pattern and pulmonary function, considering mouth and nose breathing modes. All showed normal pulmonary function values.

These findings disagree with those reported by Silveira et al. (3), who found significantly lower $\mathrm{FEV}_{1}$, $\mathrm{FVC}$ and $\mathrm{FEV}_{1} / \mathrm{FVC}$ values in mouth breathers, in addition to a negative correlation between FVC and forward head posture, suggesting that these changes tend to increase over time, resulting in an intensification of postural changes to compensate for the decline in FVC. Another study also found no difference in peak expiratory flow in adult mouth and nose breathers, but observed lower maximum respiratory pressures in mouth breathers (1).

Few studies have assessed spirometric parameters and the correlation with body posture in mouth and nose breathers. After a postural correction program, Ferreira et al. (15) obtained a significant increase in inspiratory capacity and peak expiratory flow, in addition to improved thoracic mobility and respiratory pattern in mouth breathing children. These results demonstrate the relationship between posture and respiratory function, given that body realignment seems to provide better thoracoabdominal biomechanics.

With respect to body posture, cervical distance was 6.0 and 6.2 centimeters in the mouth and nose breathing groups, respectively. The normal parameter value is six centimeters (20), with values between six and eight centimeters considered the reference $(18,21)$.

In relation to $\mathrm{HAH}$, validated for cephalometry as the measure of forward head posture (12), the values obtained in both groups declined, demonstrating that this postural deviation is present in MB and NB. The reference value currently used for this measure is $48.9^{\circ}$ (16). Studies found mean values of $46.1^{\circ}$ in NB and $47.8^{\circ}$ in MB children after physiotherapy $(15,22)$. Using photogrammetric measures similar to those of this study (HAH and CD), Weber et al. (23) found a decrease in forward head posture and reestablished cervical lordosis in mouth breathing children after postural treatment with a Swiss ball. The authors considered that postural realignment obtained by intervention promoted relaxation of accessory inspiratory muscles and improved diaphragmatic breathing.

No reference value was found for the cervical lordosis angle; however, Yi et al. (4) used this measure to assess the cervical spine and compare mouth and nose breathing children. The authors obtained a mean value of $60.36^{\circ}$ in mouth breathers and $52.27^{\circ}$ in nose breathers. In the present study, the value of this angle in children of both groups was above $60^{\circ}$, indicating a greater forward head posture also in nose breathers.

Bolzan et al. (22) assessed body posture in a similar sample to that of the present study and found postural differences between breathing modes, attributing these findings to factors such as heredity, physical activity level and physiological adaptations to growth. Furthermore, factors such as prolonged sitting (e.g. at a computer) and carrying heavy backpacks may have a negative influence on thoracic and lumbar postures (24). Neiva et al. (25) also found no difference in head posture between mouth and nose breathers, assessed objectively by means of stereogrammetry. In the physical examination, however, the authors observed forward head posture in $86 \%$ and $78 \%$ of mouth and nose breathers, respectively.

On the other hand, a number of studies have associated postural changes, primarily forward head posture, to mouth breathing $(2,3,4,26)$. In a study by Okuro et al. (2), head posture was most affected by mouth breathing, acting as a satisfactory compensatory mechanism to maintain respiratory muscle strength, irrespective of breathing mode.

A correlation between postural measures, spirometric parameters and the data of both groups showed a positive correlation between head posture and pulmonary variables, that is, greater forward head posture and less cervical lordosis seem to maintain better lung volumes and flows. The mechanical process of breathing involves rib cage movement, the diaphragm being the main muscle, which contracts during inspiration in conjunction with accessory muscles, including external intercostals, sternocleidomastoids and scalenes (27). By maintaining higher respiratory load, the diaphragm can decrease its activity, and accessory muscle recruitment, such as the sternocleidomastoid muscle, becomes necessary (28). Rib cage biomechanics does not operate independently, but in coordination with global body mechanics, underscoring the ability of the human body to adapt to different conditions (29).

By contrast, the marked forward head posture observed in both groups may cause excessive use of the cervical muscles, resulting in increased respiratory expiratory flow volumes in both mouth and nose breathing children. Forward head posture is characterized as low cervical spine flexion and extension.

In addition to mouth breathing, a number of factors have been associated with forward head posture, 
including prolonged sitting and extended use of computers and smartphones $(26,30,31)$. Sedrez et al. (24) used panoramic radiographs to investigate the risk factors associated with postural-structural changes in the spine of children and adolescents. Associations were found between inadequate postures and prolonged sitting, carrying backpacks with an asymmetrical load, sleeping more than 10 hours and lack of physical activity.

It is important to underscore that different photogrammetric measures are used to assess head posture. In this study, two measures widely used to assess head posture (HAH and CD) were applied (12), in addition to the measure of CL assessed in a study on mouth breathing children (4). This last measure should be analyzed with caution, because the acromion is a mobile point and could also be accompanied by forward head posture, without changes in the value of this angle.

Lumbar lordosis, assessed by lumbar distance, was positively correlated with PEF, FEV ${ }_{1}$ and FVC. In other words, the higher the lumbar lordosis, the greater the lung volumes and flow rates. The ideal spinal alignment is related to abdominal muscles (32). The occurrence of lumbar hyperlordodis is associated with low physical activity levels, primarily the strength of muscles that surround the spine, such as the abdominals (33). The work of these muscles becomes more effective during child development, normally between 10 and 12 years of age (34). Since muscles are arranged in networks, with functional integration between the various segments, postural changes may be global, that is, with accommodations of proximal or distal body structures.

From this analysis standpoint, it is speculated that lumbar hyperlordosis due to abdominal flaccidity and with consequent diaphragmatic disadvantage seems to be compensated by increased sternocleidomastoid muscle activity to generate higher lung volumes and flow rates, with predominantly thoracic breathing, due to greater forward head posture (35). As consequence, there may be a disadvantage in diaphragm muscle action and lack of synergism with abdominal muscles (36). It is important to underscore that these imbalances cause postural adaptations that may become progressive (4).

Considering the sample of this study, the findings do not corroborate what is normally reported in the literature: postural changes in the cervical and lumbar spine result from the excessive use of accessory muscles that leads to increased lung volumes and flow rates in childhood. Moreover, postural changes occur continuously during the entire ontogenesis, with critical periods at school age and puberty $(32,37)$. If perpetuated, mouth breathing in adulthood can cause a decrease in diaphragmatic amplitude and electrical activity of accessory muscles owing to muscle shortening (36).

Studies found in the literature, including this one, are association studies, precluding establishing a cause and effect relationship between breathing mode and postural changes.

\section{Conclusion}

No differences in postural or spirometric variables were found between mouth and nose breathers. However, mean head posture values in both groups were non-normal, indicating forward head posture.

Head and lumbar spine postures correlated with spirometric variables (PEF, FEV ${ }_{1}, \mathrm{FCV}_{\text {and }} \mathrm{FEF} 25-75 \%$ ), demonstrating that the greater the forward head posture and lumbar lordosis, the higher the lung volumes and flow rates or vice versa.

The findings of the present study do not allow establishing a cause-effect relationship between the variables; however, it is assumed that postural changes may be linked to lung volumes and flow rates through a complex biomechanical network surrounding accessory respiratory and abdominal muscles. Furthermore, there is a need for an integrated approach to musculoskeletal and respiratory systems, primarily with respect to the assessment of children.

\section{References}

1. Milanesi JM, Weber P, Berwig LC, Ritzel RA, Silva AMT, Correa ECR. Childhood mouth-breathing consequences at adult age: ventilatory function and quality of life. Fisioter Mov. 2014;27(2):211-8.

2. Okuro RT, Morcillo AM, Sakano E, Schivinski CIS, Ribeiro MAGO, Ribeiro JD. Exercise capacity, respiratory mechanics and posture in mouth breathers. Braz J Otorhinolaryngol. 2011;77(5):656-62.

3. Silveira W, Mello FCQ Guimarães FS, Menezes SLS. Postural alterations and pulmonary function of mouth-breathing children. Braz J Otorhinolaryngol. 2010;76(6):683-6. 
4. Yi LC, Jardim JR, Inoue DP, Pignatari SSN. The relationship between excursion of the diaphragm and curvatures of the spinal column in mouth breathing children. J Pediatr. 2008;84(2):171-7.

5. Lione R, Buongiorno M, Franchi L, Cozza P. Evaluation of maxillary arch dimensions and palatal morphology in mouth-breathing children by using digital dental casts. Int J Pediatr Otorhinolaryngol. 2014;78(1):91-5.

6. Abreu RR, Rocha RL, Lamounier JA, Guerra AFM. Etiology, clinical manifestations and concurrent findings in mouth-breathing children. J Pediatr. 2008;84(6):529-35.

7. Nouer DF, Souza MA, Romano FL, Coelho-Ferraz MJP. Fatores etiológicos da respiração bucal. In: Coelho-Ferraz MJP (org). Respirador bucal - uma visão multidisciplinar. São Paulo: Lovise; 2005. p. 43-9. Portuguese.

8. Santos MM, Silva MPC, Sanada LS, Alves CRJ. Análise postural fotogramétrica de crianças saudáveis de 7 a 10 anos: confiabilidade interexaminadores. Rev Bras Fisioter. 2009;13(4):360-5.

9. Poussa MS, Heliovaara MM, Seitsamo JT, Kononen MH, Hurmerinta KA, Nissinen KA. Development of spinal posture in a cohort of children from the age of 11 to 22 years. Eur Spine J. 2005;14(8):738-42.

10. Cuccia AM, Lotti M, Caradonna D. Oral breathing and head posture. Angle Orthod. 2008;78(1):77-82.

11. Souza JA, Pasinato F, Basso D, Corrêa ECR, Silva AMT. Biophotogrammetry: reliability of measurements obtained with a posture assessment software (SAPO). Rev Bras Cineantropom Desempenho Hum. 2011;13(4):299-305.

12. Weber P, Corrêa ECR, Milanesi JM, Soares JC, Trevisan MA. Craniocervical posture: cephalometric and biophotogrammetric analysis. Braz J Oral Sci. 2012;11(3):416-21.

13. Marchesan IQ Berretin-Félix G, Genaro KF. MBGR protocol of orofacial myofunctional evaluation with scores. Int J Orofacial Myology. 2012;38:38-77.

14. Sociedade Brasileira de Pneumologia e Tisiologia. Diretrizes para testes de função pulmonar. J Bras Pneumol. 2002;28(3):S1-S238.

15. Ferreira FS, Weber P, Corrêa ECR, Milanesi JM, Borin GS, Dias MF. Efeito da fisioterapia sobre os parâmetros ventilatórios e a dinâmica tóraco-abdominal de crianças respiradoras bucais. Fisioter Pesqui. 2012;19(1):8-13.
16. Raine S, Twomey LT. Head and shoulder posture variations in 160 asymptomatic women and men. Arch Phys Med Rehabil. 1997;78(11):1215-23.

17. Milanesi JM, Borin G, Corrêa ECR, Silva AMT, Bortoluzzi DC, Souza JA. Impact of the mouth breathing occurred during childhood in the adult age: Biophotogrammetric postural analysis. Int J Pediatr Otorhinolaryngol. 2011;75(8):999-1004.

18. Munhoz WC, Marques AP, Siqueira JTT. Evaluation of body posture in individuals with internal temporomandibular joint derangement. Cranio. 2005;23(4):269-77.

19. Chan YH. Biostatistics 104: correlational analysis. Singapore Med J. 2003;44(12):614-9.

20. Rocabado M. Biomechanical relationship of the craniocervical and hyoid regions. J Craniomandib Pract. 1983;1(3):61-6.

21. Souza JA, Pasinato F, Corrêa ECR, Silva AMT. Global body posture and plantar pressure distribuition in individuals with and without temporomandibular disorder: a preliminary study. J Manipulative Physiol Ther. 2014;37(6):407-14.

22. Bolzan GP, Silva AMT, Boton LM, Corrêa ECR. Study of anthropometric measurements and orofacial proportions of nasal-and mouth-breathing children from different etiologies. Rev Soc Bras Fonoaudiol. 2011;16(1):85-91.

23. Weber P, Corrêa ECR, Ferreira FS, Milanesi JM, Trevisan MA. Análise da postura craniocervical de crianças respiradoras bucais após tratamento postural em bola suíça. Fisioter Pesqui. 2012;19(2):109-14.

24. Sedrez JM, Rosa MIZ, Noll M, Medeiros FS, Candotti CT. Risk factors associated with structural postural changes in the spinal column of children and adolescents. Rev Paul Pediatr. 2015;33(1):72-81.

25. Neiva PD, Kirkwood RN, Godinho R. Orientation and position of head posture, scapula and thoracic spine in mouth-breathing children. Int J Pediatr Otorhinolarygol. 2009;73(2):227-36.

26. Uhlig SE, Marchesi LM, Duarte H, Araújo MTM. Association between respiratory and postural adaptations and self-perception of school-aged children with mouth breathing in relation to their quality of life. Braz J Phys Ther. 2015;19(3):201-10. 
27. Nason LK, Walker CM, McNeeley MF, Burivong W, Fligner CL, Godwin JD. Imaging of the diaphragm: anatomy and function. Radiographics. 2012;32(2):E51-E70.

28. Breslin EH, Garoutte BC, Kohlman-Carrieri V, Celli BR. Correlations between dyspnea, diaphragm and sternomastoid recruitment during inspiratory resistance breathing in normal subjects. Chest. 1990;98(2):298-302.

29. Almeida VP, Guimarães FS, Moço VJR, Ferreira AS, Menezes SLS, Lopes AJ. Is there an association between postural balance and pulmonary function in adults with asthma? Clinics. 2013;68(11):1421-7.

30. Lee KJ, Han HY, Cheon SH, Park SH, Yong MS. The effect of forward head posture on muscle activity during neck protraction and retraction. J Phys Ther Sci. 2015;27(3):977-9.

31. Czaprowski D, Pawlowska P, Stolisnski L, Kotwicki T. Active self-correction of back posture in children instructed with 'straighten your back' command. Man Ther. 2014;19(5):392-8.

32. Park HC, Kim YS, Seok SH, Lee SK. The effect of complex training on the children with all of the deformities including forward head, rounded shoulder posture, and lumbar lordosis. J Exerc Rehabil. 2014;10(3):172-5.

33. Lemos AT, Santos FR, Gaya ACA. Hiperlordose lombar em crianças e adolescentes de uma escola privada no Sul do Brasil: ocorrência e fatores associados. Cad Saude Publica. 2012;28(4):781-8.
34. Penha PJ, João SMA, Casarotto RA, Amino CJ, Penteado DC. Postural assessment of girls between 7 and 10 years of age. Clinics. 2005;60(1):9-16.

35. Corrêa EC, Bérzin F. Mouth breathing syndrome: cervical muscles recruitment during nasal inspiration before and after respiratory and postural exercises on swiss ball. Int J Pediatr Otorhinolaryngol. 2008;72(9):1335-43.

36. Trevisan ME, Boufleur J, Soares JC, Haygert CJP, Ries LGK, Correa ECR. Diaphragmatic amplitude and accessory inspiratory muscle activity in nasal and mouth-breathing adults: a cross-sectional study. J Electromyogr Kinesiol. 2015;25(3):463-8.

37. Dolphens M, Cagnie B, Coorevits P, Vleeming A, Vanderstraeten G, Danneels L. Classification system of the sagittal standing alignment in young adolescent girls. Eur Spine J. 2014;23(1):216-25.

Received in 08/19/2015

Recebido em 19/08/2015

Approved in 05/12/2016

Aprovado em 12/05/2016 
